standardized tests in fundamental subjects, given semi-annually, have a weight of one. "The ranking of the child is further modified in special cases by certain psychologi$\mathrm{cal}$ and psychiatric information in the principal's office."

The low ranking children, never more than twenty, are placed in what is known as the "small group," and the rest divided into nearly equal groups and taught in classes of about thirty.

"It is of interest to know," says the principal in his annual report for the year ending June 30, 1930, "that the proportion of high I. Q.'s in the small groups is as great as that in the other two groups. Lack of ability to read, lack of mastery in the fundamental processes of arithmetic, lack of emotional stability, unfortunate home conditions, and many other influences make the small-group children unable to compete in the grade with the others.

The desirability of the smallness of the group is made clear to parents and children, and insofar as seems wise, the child is told of his disabilities. It is explained to him that "he is to have an opportunity to build up his lacks and to overcome his difficulties. In no way is he made to feel that he is 'dumb' or different from other children in the school. These small groups are put into the hands of expert teachers who because of the small numbers can give these individual troubles more individual attention.

"The service facilities of the school such as the division of psychology, the division of psychiatry, the remedial division, are all at the disposal of the teacher in her year's work with the small group. As a result of the first year of this type of grouping, because of the careful analysis of each child in the small group and the focusing of the school's attention on the difficulties mentioned above, we were able to overcome, in the case of fifty per cent of the children, their difficulties and disabilities."
The fact that such a system of grouping has proved successful at Horace Mann does not mean necessarily that it is applicable to all schools, Dr. Reynolds is careful to point out. "However," he says, "the fundamental philosophy on which the Horace Mann method of grouping is based, it seems to me, is sound in the education of children. This sort of philosophy does away with the practice of handling groups of children by formulas, and substitutes education based on special attention to individual children. It assumes the validity of the psychology of individual difference and tries in a practical way to take this into consideration in the education of children. It is expensive, but is in my opinion a justifiable expense." -Private School Neres.

\section{HIGH SCHOOL AND THE STUDENT NURSE}

S HOULD I like this girl to care for me when I am sick?"

If teachers and others who advise girls to go into nursing would use this question as one criterion, they would help greatly in safeguarding health standards in their communities.

They would also keep many young women from spending unhappy years in a profession for which they are unfit, which does not want the low-grade member, and cannot support her.

This is vividly brought out in facts gathered by the Committee on the Grading of Nursing Schools. This Committee is conducting a nation-wide survey of nursing, to study ways and means of providing adequate nursing service at a price within the reach of the average person.

The survey, directed by Dr. May Ayres Burgess, educator and statistician, includes more than 150,000 replies to questionnaires from doctors, nurses, patients, student nurses, and heads of nursing schools. It is the first of its kind in the field.

It shows that the "high school failure" 
girl who goes into nursing is often a positive danger to the sick in her care. It also shows that, because patients, physicians, hospitals, and health agencies steer clear of her whenever possible, she is an economic liability, and her own professional life is a failure. Moreover, she lowers standards in a profession in which only the highest standards should prevail, because of its direct responsibility for human life.

How high school educators, even today, sometimes regard the candidate for the school of nursing, may be seen from the following letter, written by an assistant principal of a famous metropolitan high school. The letter is genuine. Only the names have been changed.

\section{"Dear Miss}

Lillie Haynes, of Section 561, has set her heart on being a nurse. Is there any opening for her? What are the requirements? Where can she apply? She is a hopeless failure in her studies, but I think she would do well in nursing."

There is a real danger in regarding nursing schools as a refuge for the dull, or a discipline for the refractory. Student nurses, often before their first year is completed, are already entrusted with life-and-death responsibility in the care of hospital patients. On a typical day studied in 1,338 schools, student nurses gave 64 per cent., or about two-thirds, of the actual bedside care to patients, in the hospitals to which the schools belong. Unless one employs a special nurse when one goes to a hospital, it is very likely one will be in the care of student nurses.

Most student nurses are only eighteen years old at entrance. Unless this immaturity is offset by a sound educational background and a keen sense of responsibility, they may jeopardize human lives.

These students, after graduation, will be responsible for the community's health, as public health nurses, industrial nurses, school nurses, bedside nurses in the homes of patients or in hospitals, and directors of entire hospitals or of hospital nursing services.

The heavy demands of modern medicine have brought into the curriculum of the nursing school such difficult studies as anatomy, physics, chemistry, sociology, and psychology. Without at least a sound high school preparation, the student nurse is likely to find this work too hard. She either leaves, or is asked to resign from the school. She may spend months trying to learn, and the school much time and money trying to teach her a profession she should never have attempted. Aside from formal study, the student nurse must have the intelligence also to correlate what she has learned in the classroom with the actual work she does in the hospital, and to make the right approach to patients, a most important aspect of nursing care.

The better nursing schools now require a four-year high school diploma for entrance, together with evidence that the student stood in the upper half of her class. The high school diploma requirement is rapidly on the increase, through State law, and through the voluntary decision of many school heads. At present, 73 per cent. of 59,612 student nurses are high school graduates. Eight per cent. have also had a year or more of college. More than 16,000 , however, still do not meet this essential requirement.

The high school program of the student who contemplates taking up nursing should include science courses, chemistry, physics, biology, bacteriology, sociology, psychology, ethics, and economics. It should also include household science, cookery, nutrition. The general all-round course, with emphasis on cultural and scientific subjects, seems to give the best foundation on which to build a nursing training.

The fine type of high school graduate is eligible for entrance to the better nursing schools; she is equipped to grasp the difficult studies and procedures now included in the nursing course; and she can qualify for the high positions in her profession. There is a decided need for the high quality young woman in executive positions and as nurse teachers. 
If the nursing school should accept the girl who has not completed high school, she will find upon graduation that the majority of the better opportunities in nursing are closed to her. Her future in general is apt to be precarious.

From the point of view of both the community, and the individual patient, the intelligent, well-educated nurse is the only one to whom the lives of the sick should be entrusted.

When more than 4,000 physicians were approached, they were emphatic in demanding nurses of good breeding, good background, and fine training. Patients also want their nurses to have intelligence, breeding, and education. While patients are generally satisfied with the nurses they employ, they make such comments as the following: "My criticism is that applicants for training schools should be considered more carefully before being taken into training. Some of them are sadly lacking in education."

A high school diploma, a high class standing, and intelligence are the basic requirements for a worth while student nurse. Other important qualifications are good health, a real liking for people, conscientiousness, good breeding, and a professional attitude.

\section{Martha Dreiblatt}

A public government without public information or the means of acquiring it is but a prologue to a farce or a tragedy, or perhaps both. Knowledge will forever govern ignorance, and a people who mean to be their own governors must arm themselves with the power which knowledge gives.-JAMES MADISON.

No man can reach the front rank if he is not intelligent and if he is not trained with intelligence.-TheOdoRE Roosevelt.

Knowledge is in every country the surest basis of public happiness.

\section{-George Washington.}

\section{THE PRESIDENT'S COLUMN}

D URING the early part of January, Hon. Harris H. Hart, who has been the State Superintendent of Public Instruction for more than twelve years, retired from this office to become associated with the Johnson Publishing Company. Anyone connected with the public school system of Virginia during Mr. Hart's incumbency in office must have been impressed with the great progress that the Virginia system of education made under his leadership. The progress of public education in Virginia was outstanding among that of all states in the union and especially in the improvement of the teaching force. Virginia is fortunate, however, in that a young, vigorous, well-trained leader was promptly selected by Governor Pollard in the person of Dr. Sidney B. Hall, a Virginian who, at the time of his appointment, was a member of the faculty of George Peabody College at Nashville. We predict for Dr. Hall the same type of cooperation that the people of Virginia gave to Mr. Hart and believe that his leadership will be of the same constructive type that characterized Mr. Hart's administration. We sincerely trust that every teacher in Virginia will loyally stand behind him in his efforts to improve public education.

\section{Elevated Standards}

In line with the above comment regarding the improvement of the teaching force, it might be well to mention the fact that the elementary certificate for teachers in the public schools of Virginia will no longer be issued to new teachers after July 1, 1931. It is true, however, that the entire summer of 1931 may be used for the completion of the elementary certificate, although this certificate may be dated as of July 1st. This statement means that, after July 1st, the minimum training for teachers coming into the public school system of Virginia will 